\title{
Antibodies anti-Toxoplasma gondii and anti-Neospora caninum in backyard pigs from the state of Mato Grosso, Brazil
}

\author{
Anticorpos anti-Toxoplasma gondii e anti-Neospora caninum em porcos de criaçóes de fundo de quintal do \\ Estado de Mato Grosso, Brasil \\ Make Kawatake Minetto ${ }^{1,2}$; Rute Witter ${ }^{1,3}$; Anderson Castro Soares de Oliveira ${ }^{1}$; João Augusto Minetto ${ }^{2}$; \\ Marcelo Luís Barros²; Daniel Moura de Aguiar ${ }^{1}$; Richard de Campos Pacheco ${ }^{1 *}$ \\ ${ }^{1}$ Programa de Pós-graduação em Ciências Veterinárias - PPGVET, Faculdade de Medicina Veterinária - FAVET, Universidade Federal \\ de Mato Grosso - UFMT, Cuiabá, MT, Brasil \\ ${ }^{2}$ Instituto de Defesa Agropecuária do Estado de Mato Grosso - INDEA-MT, Cuiabá, MT, Brasil \\ ${ }^{3}$ Instituto Federal de Educação, Ciência e Tecnologia de Rondônia - IFRO, Jaru, RO, Brasil
}

Received February 19, 2019

Accepted June 5, 2019

\begin{abstract}
To estimate the seroprevalence of Toxoplasma gondii and Neospora caninum, using an indirect immunofluorescent assay (IFA), and identify the risk factors associated, serum samples were collected from 1,070 pigs from 320 backyard pig farming in the of Mato Grosso state. The animal-level seroprevalence of T. gondii and N. caninum was 32.48\% and $13.49 \%$, respectively, with a herd seroprevalence of $55.63 \%$ for $T$. gondii and $27.81 \%$ for $N$. caninum. Feeding the animals with leftovers increases the probability of the presence of anti- $T$. gondii antibodies in pigs by 1.09 -fold. Unlike to T. gondii, feeding with leftovers was found to be negatively associated with $N$. caninum seropositivity in farm-level analysis and in the animal-level model, so decreasing the chances of positivity. Yet, age was considered a risk factor for $N$. caninum seropositivity. Further studies are necessary to evaluate the impact of T. gondii infection on backyard pig farming production, and its importance as a source of toxoplasmosis infection in humans in the Mato Grosso state, as well as, the role of domestic pigs in the epidemiology of neosporosis.
\end{abstract}

Keywords: Toxoplasmosis, neosporosis, seroprevalence, risk factors.

\section{Resumo}

Para estimar a soroprevalência de Toxoplasma gondii e Neospora caninum, utilizando a reação de imunofluorescência indireta (RIFI), e identificar os fatores de risco associados, foram coletadas amostras de soro de 1.070 suínos provenientes de 320 criatórios de fundo de quintal no Estado de Mato Grosso. A soroprevalência para nível animal de T. gondii e $N$. caninum foi de $32,48 \%$ e 13,49\%, respectivamente, com uma soroprevalência de rebanho de 55,63\% para T. gondii e $27,81 \%$ para $N$. caninum. Alimentar os animais com sobras aumenta a probabilidade da presença de anticorpos anti-T. gondii em porcos em 1,09 vezes. Ao contrário de T. gondii, a alimentação baseada em sobras foi encontrada como negativamente associada à soropositividade para $N$. caninum na análise em nível de fazenda e no modelo em nível animal, diminuindo assim as chances de positividade. Ainda, a idade foi considerada um fator de risco para a soropositividade para $N$. caninum. Mais estudos são necessários para avaliar o impacto da infecção por $T$. gondii na produção de suinocultura de quintal e sua importância como fonte de infecçáo para toxoplasmose em humanos no Estado de Mato Grosso, bem como o papel dos suínos domésticos na epidemiologia da neosporose.

Palavras-chave: Toxoplasmose, neosporose, soroprevalência, fatores de risco.

\section{Introduction}

Toxoplasma gondii is a coccidian parasite with cats as definitive hosts, and warm-blooded animals as intermediate hosts (DUBEY, 2010). Serological surveys have reported $T$. gondii infection to be

${ }^{*}$ Corresponding author: Richard de Campos Pacheco. Programa de Pós-graduação em Ciências Veterinárias - PPGVET, Faculdade de Medicina Veterinária - FAVET, Universidade Federal de Mato Grosso - UFMT, Av. Fernando Corrêa da Costa, 2367, Boa Esperança, CEP 78060-900, Cuiabá, MT, Brasil. e-mail: richard@ufmt.br prevalent in pigs worldwide (DUBEY, 2009), and up to $90 \%$ of pigs surveyed in Brazil had T. gondii antibodies (DUBEY et al., 2012). The seroprevalence varied dramatically among the different classes surveyed, such as market pigs versus sows and indoor pigs from bio secure housing systems in contrast with free-range (DUBEY, 2010).

Tissue cysts of $T$. gondii have been found in meat, meat-derived products, or offal (TENTER, 2009), and among the food animals, 
infected pigs and pork products are the most likely meat source of $T$. gondii infection for people in many countries (DUBEY, 2009), including Brazil (DUBEY et al., 2012).

Neospora caninum is a recently recognized protozoan parasite that was misidentified as $T$. gondii until 1988. This coccidian parasite uses canids (dogs, coyotes, dingoes and grey wolves) as definitive hosts and warm-blooded animals as intermediate hosts (DUBEY et al., 2017).

Information on seroprevalence of $N$. caninum in domestic pigs is limited worldwide (DUBEY et al., 2017), with low N. caninum seropositivity observed in this species from Brazil (AZEVEDO et al., 2010; FEITOSA et al., 2014).

Mato Grosso state in midwestern Brazil is the fifth largest producer of pigs in the country, with 2,613,925 million animals distributed in 34,093 farms; of this total, $98.78 \%$ are backyard pig farming, and make up $16.76 \%$ of the total population of pigs from the state (INDEA, 2016). The aim of the study was to evaluate the presence of anti- $T$. gondii and anti- $N$. caninum antibodies in pigs from backyard pig farming establishments in Mato Grosso state, Brazil, and identified the risk factors associated with the seropositivity.

\section{Materials and Methods}

\section{Study area, serum collection and epidemiological information}

Blood samples had been collected for a field surveillance as part of the National Programme for Control and Eradication of classical swine fever (CSF), by the Mato Grosso Institute for Agricultural Defense (INDEA/MT), in the state of Mato Grosso, midwestern Brazil, between September and December 2014. Then the stored samples were made available for the present study.

\section{Sampling}

The sample was carried out following the criteria established in the Manual of standardization seroepidemiological survey in swine farms (BRASIL, 2010). The procedure of selecting sample was done in 2 stages. The first stage (called primary sampling units) involved selecting a predetermined number of random farms.

The procedure of selecting sample was done in 2 stages. The first stage (called primary sampling units) involved selecting a predetermined number of random farms, and the sample size was calculated using the following algebraic expression, previously described (SCHEAFFER et al., 2011):

$$
n=\frac{\frac{z_{\alpha}^{2}}{2} p(1-p) N}{(N-1) d^{2}+z_{\frac{\alpha}{2}}^{2} p(1-p)}
$$

Thus, we considered the total number of farms 3,397, expected proportion of positive farms $p=0.50$ (due to the absence of prior studies), maximum error of estimate $\mathrm{d}=0.055$, and, $z_{\frac{\alpha}{2}}=1.96$ is the value of standard normal distribution table, for a $95 \%$ confidence interval (CI). This resulted in a sample of 320 farms, characteristically with pigs reared for their own consumption, in family-run farms with no industrial features.

Sampling of animals from each farm remained the same presented in field surveillance conducted by INDEA/MT. Concurrent with sampling, epidemiological data were collected through questionnaire survey and used for the risk factor analysis.

Following this, a predetermined number of pigs (called secondary sampling units) aged over 8 months were sampled. For the secondary sampling unit, sample size was pre-established considering the number of pigs older than 8 months on each farm, minimum prevalence of farms and adult animals positives of $1 \%$ and $10 \%$, respectively, $95 \%$ of probability of detecting a positive farm, and $95 \%$ of sensitivity of the herd. Considering the number of animals on each farm, the criteria was as follows: all pigs were sampled from farms with up to 15 pigs; 15 pigs were sampled from farms with $16-20$ pigs; 20 from farms with 21-30 pigs; 23 from farms with 31-50 pigs; 26 from farms with 51-80 pigs; and finally, 30 were sampled from farms with over 80 pigs. Thus, total 1,070 serum samples were randomly collected.

\section{Indirect immunofluorescence assay}

Serum samples were analyzed individually for anti- $T$. gondii and anti- $N$. caninum IgG antibodies by indirect immunofluorescence assay (IFA), as described by Camargo (1964) and Azevedo et al. (2010), respectively. RH strain and isolate NC-1 tachyzoites of T. gondii and N. caninum, respectively, maintained in Vero cell cultures and fixed on slides were used as target antigens, along with anti-pig IgG conjugate (Sigma, St Louis, MO, USA), at a 1:100 dilution. Serum samples were considered positive when the majority of fixed tachyzoites ( $>50 \%$ ) showed complete peripheral fluorescence at 1:64 (GARCIA et al., 1999) and 1:50 (AZEVEDO et al., 2010) dilutions for T. gondii and N. caninum, respectively. All the seropositive serum samples were retested using 2-fold serial dilutions. Positive and negative pig sera were used as controls.

\section{Seroprevalence and statistical analysis}

We expressed the seroprevalence of $T$. gondii and $N$. caninum on the farms and among the animals in the form of estimated value and confidence intervals, according to Thrusfield (2007). Furthermore, to calculate the seroprevalence of $T$. gondii and $N$. caninum among the animals were used weighted values (DOHOO et al., 2003). The following expression was used to determine the weighted value for each animal:

$\frac{\text { Total number of }>8 \text { month }- \text { old pigs }}{\text { total of }>8 \text { month pigs sampled } * \frac{\text { total of }>8 \text { month }- \text { old pigs on the farm }}{\text { total of }>8 \text { month }- \text { old pigs sampled on the farm }}}$

In the farm-level analysis, to describe the seroprevalence of $T$. gondii and $N$. caninum, each farm was analyzed under the assumption that a farm would be considered positive if at least one animal tested seropositive. The following steps were taken in order to create a multiple logistic regression model. Firstly, for continuous variables, a linearity test was carried out using 
Graphs for Log Odds. The continuous variable was categorized if the visual evaluation shown a nonlinear trend. We used the optimization methodology of the R package CatPredi, as described (BARRIO et al., 2017). Secondly, regarding the categorical variables, we used a chi-square or Fisher's exact test on the results, and then we included into the model the various predictor variables, and all the variables with a value of $\mathrm{p}<0.20$. Thirdly, we tested the selected variables for collinearity, including multicollinearity analysis (VATCHEVA et al., 2016). This ensured a mean variance inflation factor $(\mathrm{VIF})<10$, before fitting them into my model. Finally, all the variables selected, as previously described, were included to build the model. Based on the Wald test, we removed the least significant variables, and the logistic regression analysis was repeated. Once repeated, the adjusted model was compared to the previous model using likelihood ratio test to verify for confounding factors. In case of a change greater than $30 \%$ in the parameter estimates, we considered the removed variable a confounding factor, and once more included in the model.

The following variables were used to build the herd model for T. gondii: farm is in the rural areas or near indigenous reserves (yes or no); farm is in the peri-urban areas or poor communities (yes or no); pigs were raised extensively (yes or no); feeding with leftovers (yes or no); presence of cats (yes or no); farm is located near dumps (yes or no); creates or fattens (yes or no); farm is close to environmental reserves (yes or no); slaughtering on the farm (yes or no).

Herd model for $N$. caninum was building using the following variables: farm is in the rural areas or near indigenous reserves (yes or no); farm is in the peri-urban areas or poor communities (yes or no); pigs were raised extensively (yes or no); feeding with leftovers (yes or no); presence of dogs (yes or no); farm is located near dumps (yes or no); creates or fattens (yes or no); farm is close to environmental reserves (yes or no); slaughtering on the farm (yes or no).

For animal-level analysis, we followed the same steps presented above to analyze the farms. However, in order to correct the effect of animal selection for which weighted values were used, and described above, we applied a complex analysis to the tests, as previously described (KORN \& GRAUBARD, 1999).

The variables used to build the model for T. gondii were: sex (male or female); feeding with leftovers (yes or no); presence of cats (yes or no); farm is located near dumps (yes or no). While the following variables were used to construct the model for N. caninum: sex (male or female); feeding with leftovers (yes or no); presence of dogs (yes or no); farm is located near dumps (yes or no). R statistical software package (R DEVELOPMENT CORE TEAM, 2013) were used for statistical analysis.

\section{Ethics statement}

In this study, all procedures using animals complied with the Ethical Principles in Animal Research adopted by the College of Animal Experimentation (COBEA) and were approved (protocol number 23108.215.014/2017-80) by the Animal Research Ethics Committee of the Federal University of Mato Grosso, Brazil.

\section{Results}

Of the 320 farms analyzed, anti-T. gondii and anti- $N$. caninum antibodies were detected in at least one animal in 178 and 89 farms (Figure 1), respectively; this resulted in a herd seroprevalence of 55.63\% (CI 95\%; 50.18\%; 61.07\%) for T. gondii and $27.81 \%$ (CI 95\%; 22.90\%; 32.72\%) for N. caninum. Moreover, the

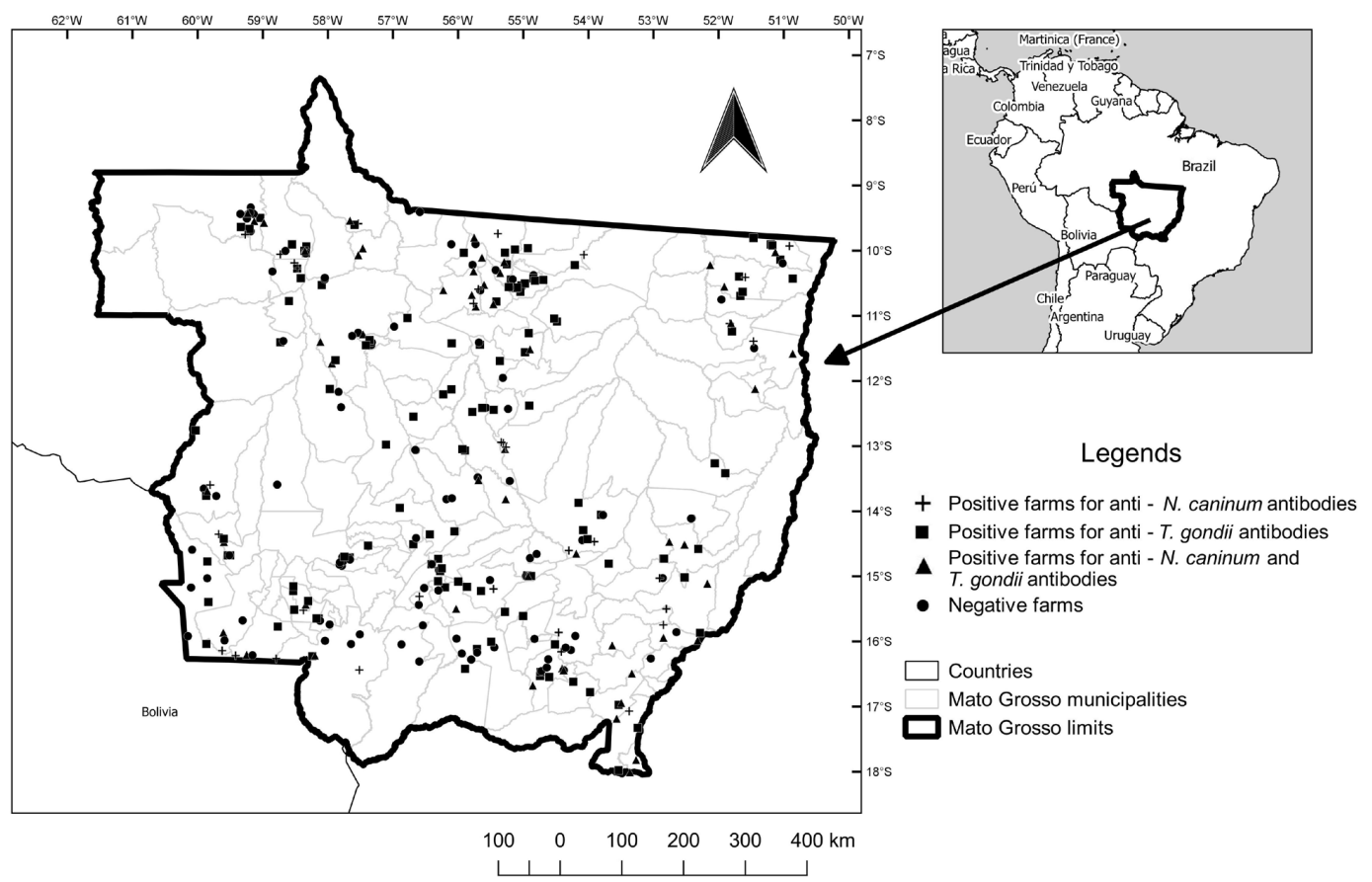

Figure 1. Spatial distribution of the 320 farms sampled for the detection of anti-Toxoplasma gondii and anti-Neospora caninum of the Mato Grosso state, Brazil, between September and December 2014. 
seroprevalence of $T$. gondii in the total population was $32.48 \%$ (CI 95\%; 28.49\%; 36.46\%), with titers ranging from 64 to 8,192 , while that of $N$. caninum was $13.49 \%$ (CI 95\%; 10.89\%; 16.02\%), and titers ranged from 50 to 6,400. Distribution of endpoint titers among the positive animals for $T$. gondii and $N$. caninum are listed in Table 1.

The relationship between the presence of anti-T. gondii and anti- $N$. caninum antibodies and the variables of the logistic model on the 320 farms sampled are summarized in Table 2. In farm-level analysis, no variable was found to be significantly associated with the seroprevalence of $T$. gondii in pigs, after the model of multivariate analysis was applied. However, feeding with leftovers was found to be negatively associated with the presence of $N$. caninum seropositive pigs on farms, since farms that provide feeding with leftovers were $38.13 \%$ less likely to have pigs testing positive for $N$. caninum (Table 3 ).

Table 1. Results of indirect immunofluorescence assay (IFA) endpoint titers obtained among 1,070 pigs (> 8 months) on 320 farms of the state of Mato Grosso, Brazil, between September and December 2014, using Toxoplasma gondii and Neospora caninum antigens.

\begin{tabular}{cccc}
\hline Endpoint antibody titers & $\begin{array}{c}\mathbf{N}^{\circ} \text {. seroreactive sera to } \\
\text { Toxoplasma gondii }(\%)\end{array}$ & Endpoint antibody titers & $\begin{array}{c}\text { No. seroreactive sera to } \\
\text { Neospora caninum }(\%)\end{array}$ \\
\hline 64 & $82(23.63)$ & 50 & $65(45.13)$ \\
128 & $114(32.85)$ & 100 & $47(32.63)$ \\
256 & $79(22.76)$ & 200 & $16(11.11)$ \\
512 & $45(12.96)$ & 400 & $11(7.63)$ \\
1,024 & $8(2.3)$ & 800 & $1(0.69)$ \\
2,048 & $9(2.59)$ & 1,600 & $3(2.08)$ \\
4,096 & $7(2.01)$ & 3,200 & 0 \\
8,192 & $3(0.86)$ & 6,400 & $1(0.69)$ \\
Total of seropositives & $\mathbf{3 4 7}$ & & $\mathbf{1 4 4}$ \\
Total of seronegatives & $\mathbf{7 2 3}$ & & $\mathbf{9 2 6}$ \\
\hline
\end{tabular}

Table 2. Relationship between the presence of anti-Toxoplasma gondii and anti-Neospora caninum antibodies and variables of the logistic model, on the 320 farms sampled in the of Mato Grosso state, Brazil, between September and December 2014.

\begin{tabular}{|c|c|c|c|c|}
\hline \multirow{2}{*}{ Associated variable } & \multicolumn{2}{|c|}{ Toxoplasma gondii } & \multicolumn{2}{|c|}{ Neospora caninum } \\
\hline & Positive (\%) & Negative (\%) & Positive (\%) & Negative (\%) \\
\hline \multicolumn{5}{|c|}{ Farm is in the rural areas or near indigenous reserves } \\
\hline Yes & $96(30)$ & $224(70)$ & $41(12.8)$ & $279(87.2)$ \\
\hline No & $85(26.6)$ & $235(73.4)$ & $48(15)$ & $272(85)$ \\
\hline \multicolumn{5}{|c|}{ Farm is in the peri-urban areas or poor communities } \\
\hline Yes & $27(8.4)$ & $293(91.6)$ & $74(23.2)$ & $246(76.8)$ \\
\hline No & $151(47.2)$ & $169(52.8)$ & $15(4.7)$ & $305(95.3)$ \\
\hline \multicolumn{5}{|l|}{ Pigs were raised extensively } \\
\hline Yes & $42(13.1)$ & $278(86.9)$ & $29(9.1)$ & $291(90.9)$ \\
\hline No & $136(42.5)$ & $184(57.5)$ & $60(18.8)$ & $260(81.2)$ \\
\hline \multicolumn{5}{|l|}{ Feeding with leftovers } \\
\hline Yes & $58(18.1)$ & $262(81.9)$ & $45(14.1)$ & $275(85.9)$ \\
\hline No & $120(37.5)$ & $200(62.5)$ & $44(13.7)$ & $276(86.3)$ \\
\hline \multicolumn{5}{|l|}{ Presence of cats* } \\
\hline Yes & $50(15.6)$ & $270(84.4)$ & $\mathrm{n} / \mathrm{t}^{* * *}$ & $\mathrm{n} / \mathrm{t}$ \\
\hline No & $128(40)$ & $192(60)$ & $\mathrm{n} / \mathrm{t}$ & $\mathrm{n} / \mathrm{t}$ \\
\hline \multicolumn{5}{|l|}{ Presence of dogs** } \\
\hline Yes & $\mathrm{n} / \mathrm{t}$ & $\mathrm{n} / \mathrm{t}$ & $4(1.2)$ & $316(98.2)$ \\
\hline No & $\mathrm{n} / \mathrm{t}$ & $\mathrm{n} / \mathrm{t}$ & $85(26.6)$ & $235(73.4)$ \\
\hline \multicolumn{5}{|l|}{ Farm is located near dumps } \\
\hline Yes & $6(1.9)$ & $314(98.1)$ & $6(1.9)$ & $314(98.1)$ \\
\hline No & $172(53.8)$ & $148(46.2)$ & $83(25.9)$ & $237(74.1)$ \\
\hline \multicolumn{5}{|l|}{ Farm is close to environmental reserves } \\
\hline Yes & $70(21.9)$ & $250(78.1)$ & $43(13.4)$ & $277(86.5)$ \\
\hline No & $108(33.7)$ & $212(66.3)$ & $46(14.3)$ & $274(85.7)$ \\
\hline \multicolumn{5}{|l|}{ Slaughtering on the farm } \\
\hline Yes & $12(3.7)$ & $308(96.3)$ & $7(2.2)$ & $313(97.8)$ \\
\hline No & $166(51.9)$ & $154(48.1)$ & $82(25.6)$ & $238(74.4)$ \\
\hline
\end{tabular}

${ }^{*}$ variable used only for T. gondii; ${ }^{* *}$ variable used only for N. caninum; ${ }^{* * *} \mathrm{n} / \mathrm{t}=$ not applicable. 
Table 3. Results of the logistical regression model for risk factors associated with finding in farm-level analysis and in the animal-level model for Toxoplasma gondii and Neospora caninum seropositivity, among 1070 pigs (> 8 months) on 320 farms of the state of Mato Grosso, Brazil, between September and December 2014.

\begin{tabular}{|c|c|c|c|c|c|c|c|}
\hline \multirow{2}{*}{ Analysis level } & Protozoa species & \multirow{2}{*}{ Estimate } & \multirow{2}{*}{$\mathrm{SE}^{*}$} & \multirow{2}{*}{ p-value } & \multirow{2}{*}{$\mathbf{O R}^{* *}$} & \multirow{2}{*}{\multicolumn{2}{|c|}{$\mathrm{CI}^{* * *} 95 \%$}} \\
\hline & Associated variable & & & & & & \\
\hline \multirow{2}{*}{ Farm-level analysis } & Neospora caninum & & & & & & \\
\hline & Feeding with leftovers & -0.79 & 0.03 & $<0.01$ & 0.61 & 0.26 & 0.75 \\
\hline \multirow[t]{5}{*}{ Animal-level analysis } & Toxoplasma gondii & & & & & & \\
\hline & Feeding with leftovers & 0.09 & 0.02 & 0.01 & 1.09 & 1.01 & 1.18 \\
\hline & Age & $<0.01$ & $<0.01$ & $<0.01$ & 1.0029 & 1.0008 & 1.0051 \\
\hline & N. caninum & & & & & & \\
\hline & Feeding with leftovers & -0.05 & 0.01 & 0.03 & 0.94 & 0.89 & 0.99 \\
\hline
\end{tabular}

*Standard error; ${ }^{* *}$ Odds Ratio; ${ }^{* *}$ Confidence interval.

Table 4. Relationship between the presence of anti-Toxoplasma gondii and anti-Neospora caninum antibodies and variables of the logistic model, on the pigs sampled in the of Mato Grosso state, Brazil, between September and December 2014.

\begin{tabular}{|c|c|c|c|c|}
\hline \multirow{2}{*}{ Associated variable } & \multicolumn{2}{|c|}{ Toxoplasma gondii } & \multicolumn{2}{|c|}{ Neospora caninum } \\
\hline & Positive (\%) & Negative (\%) & Positive (\%) & Negative (\%) \\
\hline \multicolumn{5}{|l|}{ Sex } \\
\hline M & $138(12.8 \%)$ & $932(87.1 \%)$ & $46(4.2 \%)$ & $1024(95.7 \%)$ \\
\hline $\mathrm{F}$ & $210(19.6 \%)$ & $860(80.3 \%)$ & $98(9.1 \%)$ & $972(90.8 \%)$ \\
\hline \multicolumn{5}{|l|}{ Farm next to the dumping ground } \\
\hline Yes & $12(1.12 \%)$ & $1.058(98.8 \%)$ & $12(1.12 \%)$ & $1058(98.8 \%)$ \\
\hline No & $335(31.3 \%)$ & $735(68.9 \%)$ & $133(12.4 \%)$ & $937(87.5 \%)$ \\
\hline \multicolumn{5}{|l|}{ Feeding with leftovers } \\
\hline Yes & $240(22.4 \%)$ & $830(77.5 \%)$ & $45(4.2 \%)$ & $275(25.7 \%)$ \\
\hline No & $107(10 \%)$ & $963(90 \%)$ & $44(4.1 \%)$ & $276(25.7 \%)$ \\
\hline \multicolumn{5}{|l|}{ Presence of cats* } \\
\hline Yes & $103(9.6 \%)$ & $967(90.3 \%)$ & $\mathrm{n} / \mathrm{t}$ & $\mathrm{n} / \mathrm{t}$ \\
\hline No & $243(22.7)$ & $827(77.2 \%)$ & $\mathrm{n} / \mathrm{t}$ & $\mathrm{n} / \mathrm{t}$ \\
\hline \multicolumn{5}{|l|}{ Presence of dogs** } \\
\hline Yes & $\mathrm{n} / \mathrm{t}^{* * *}$ & $\mathrm{n} / \mathrm{t}$ & $101(9.43 \%)$ & $969(90.5 \%)$ \\
\hline No & $\mathrm{n} / \mathrm{t}$ & $\mathrm{n} / \mathrm{t}$ & $43(4.01 \%)$ & $1027(95.9 \%)$ \\
\hline
\end{tabular}

*variable used only for T. gondii; ${ }^{* *}$ variable used only for $N$. caninum; ${ }^{* * *} \mathrm{n} / \mathrm{t}=$ not applicable.

The relationship between the presence of anti- $T$. gondii and anti- $N$. caninum antibodies and the variables of the logistic model of the 1,070 pigs sampled is shown in Table 4. In animal-level model for $T$. gondii seropositivity, one variable (feeding with leftovers) was found to be a risk factor, since pigs that were fed with leftovers were 1.09 times more likely to test positive for anti- $T$. gondii antibodies. In accordance with the farm-level analysis, the variable feeding with leftovers also appeared to be negatively associated, decreasing the chances of positivity, and pigs feeding with leftovers were $5.44 \%$ less likely to test positive for $N$. caninum antibodies. Finally, age was a variable significantly associated, considered a risk factor, since in 8-month-old pigs, with each added month of life, the animals were 1.0029 times more likely to be seroreactive to $N$. caninum (Table 3 ).

\section{Discussion}

Here, we provide a serological survey for the presence of antibodies anti- $T$. gondii and anti- $N$. caninum in family-run farms with no technological improvements. We observed that more than half of studied farms (55.63\% of herd seroprevalence) had at least one animal testing positive for anti- $T$. gondii antibodies. Moreover, a high rate seroprevalence $(32.48 \%$ ) in the total population of the present study was similarly observed in a previous survey performed in the western Amazon (CAVALCANTE et al., 2006); southern (CADEMARTORI et al., 2014) and northeastern (SAMICO-FERNANDES et al., 2017) regions from Brazil, where pigs were raised in similar conditions. 
In addition, we observed a low seroprevalence for $T$. gondii as compared to the previous serological survey performed at 3 commercial farms of Nova Mutum and Diamantino municipalities, state of Mato Grosso in 2010, where Muraro et al. (2010) found that $12.8 \%$ of the tested animals were seropositive. Probably, the higher seroprevalence rate was influenced by the management systems, once according to Bezerra et al. (2009), the level of technology is a determining factor for infection by $T$. gondii in pig farms, since higher prevalence of $T$. gondii antibodies are observed in pigs raised extensively in free-range farms than from intensive farms (VAN DER GIESSEN et al., 2007).

Notably, the sampled farms raised pigs for their own consumption, where the animals were slaughtered on the farm without any inspection, so this type of management causes exposure of farmers or people, who slaughter or even consume pork meat, to $T$. gondii infection, as pigs are considered an important source of toxoplasmosis infection in humans (DUBEY, 2010). Indeed, humans may get infected by several routes, and there are numerous reports tracing toxoplasmosis to the consumption of infected meat with some serological surveys incriminating meat more strongly than cats, as a source of human infection (DUBEY, 2010). On the other hand, humans may also get infected during evisceration and handling of the meat (TENTER, 2009).

Feeding the animals with leftovers increases the probability of the presence of anti-T. gondii antibodies in pigs by 1.09 -fold. This practice has already been associated with risk factors for $T$. gondii seropositivity (ALVARADO-ESQUIVEL et al., 2014; FEITOSA et al., 2014), suggesting that food containing raw or undercooked meat, as well as, unwashed vegetables (ALVARADO-ESQUIVEL et al., 2014; FEITOSA et al., 2014), accounts in part for the $T$. gondii infection in pigs. However, this hypothesis needs evidence. Indeed, the type of food can influence $T$. gondii seropositivity rates, since Dubey et al. (1992) observed that garbage-fed pigs had a higher seroprevalence of $T$. gondii (67.3\%) than grain-fed pigs (33.8\%), in a study conducted in Hawaii.

The seroprevalence of $N$. caninum is relative higher (13.49\%) with animals presenting titers up to 6,400 , when compared to previous studies conducted in Brazil using the same diagnostic method (IFA) and cut-off (1:50). The seroprevalence varied from $3.1 \%$ to $3.2 \%$ in domestic pigs in the country (AZEVEDO et al., 2010; FEITOSA et al., 2014). However, except for these serological evidences, currently there is no credible proof on the actual role of pigs in the epidemiology of $N$. caninum. In fact, only one study demonstrated experimental neosporosis in pigs with transplacental transmission of $N$. caninum (JENSEN et al., 1998), but there has not been any isolation of $N$. caninum from pigs in natural conditions till date.

Unlike to $T$. gondii, feeding with leftovers was negatively associated with $N$. caninum seropositivity in farm-level analysis and in the animal-level model. Although we are not aware of any study in literature reporting such an association, this management (feeding with leftovers) appeared not to be an important route of infection for $N$. caninum. How pigs acquire $N$. caninum infections in nature is not fully understood. Probably, horizontal transmission by ingestion of sporulated oocysts from food and water contaminated with dog feces represents the main route of infection, since differently as observed for $T$. gondii, the number of $N$. caninum in tissues of chronically infected animals is low (DUBEY et al., 2017), therefore, the route of infection by ingested bradyzoite in the encysted stage of the parasite in tissues seems to be not important. However, further studies are needed to prove this statement.

Finally, $N$. caninum seroprevalence rates increased with age. Though this variable was never found to be associated with N. caninum seropositivity in pigs (CERQUEIRA-CÉZAR et al., 2017), several studies demonstrated that age was a statistically significant factor, probably due to the increase in probability of horizontal transmission by ingestion of sporulated oocysts. We believe that management facilities allow greater exposure of contaminated environments, since most farms (69.68\%) recorded the presence of dogs, a known definite host for $N$. caninum.

\section{Conclusion}

We identified a high seroprevalence of $T$. gondii and $N$. caninum in pigs raised on family-run farms with no technological improvements. Feeding with leftovers was found to be risk factor for the seroprevalence of $T$. gondii in the animal-level analysis. Unlike to $T$. gondii, feeding with leftovers was negatively associated with $N$. caninum seropositivity in farm-level analysis and in the animal-level model, showing that this route of infection is probably not important for $N$. caninum. Furthermore, $N$. caninum seroprevalence rates increased with age. So, further studies are necessary to evaluate the impact of $T$. gondii on backyard pig farming production, as well as, its importance as a source of toxoplasmosis infection in humans in the Mato Grosso state, and the role of domestic pigs in the epidemiology of neosporosis.

\section{Acknowledgements}

The authors gratefully acknowledge Fundação de Amparo à Pesquisa do Estado de Mato Grosso - FAPEMAT (grant \# 0214057/2017) for its financial support of this work, and Conselho Nacional de Desenvolvimento Científico e Tecnológico (CNPq) for the awarding a research productivity grant to D.M. Aguiar and R.C. Pacheco.

\section{References}

Alvarado-Esquivel C, Romero-Salas D, García-Vázquez Z, Crivelli-Diaz M, Barrientos-Morales M, Lopez-de-Buen L, et al. Seroprevalence and correlates of Toxoplasma gondii infection in domestic pigs in Veracruz State, México. Trop Anim Health Prod 2014; 46(4): 705-709. http:// dx.doi.org/10.1007/s11250-014-0551-3. PMid:24510223.

Azevedo SS, Pena HF, Alves CJ, Guimarães AA Fo, Oliveira RM, Maksimov P, et al. Prevalence de anti-Toxoplasma gondii e Neospora caninum antibodies in swine from Northeastern Brazil. Rev Bras Parasitol Vet 2010 19(2): 80-84. http://dx.doi.org/10.1590/S1984-29612010000200002. PMid:20624342.

Barrio I, Arostegui I, Rodríguez-Álvarez MX, Quintana JM. A new approach to categorizing continuous variables in prediction models: proposal and validation. Stat Methods Med Res 2017; 26(6): 2586-2602. http://dx.doi.org/10.1177/0962280215601873. PMid:26384514. 
Bezerra RA, Paranhos EB, Del'Arco AE, Albuquerque GR. Detecção de anticorpos anti-Toxoplasma gondii em suínos criados e abatidos no Estado da Bahia, Brasil. Rev Bras Parasitol Vet 2009; 18(3): 78-80. http://dx.doi. org/10.4322/rbpv.01803015. PMid:19772782.

Brasil. Ministério da Agricultura, Pecuária e Abastecimento. Sistema de vigilância sanitária na zona livre de peste suina clássica: manual de padronização inquérito soroepidemiológico em criatórios de suideos [online]. Brasília; 2010 [cited 2019 Apr 30]. Available from: http://www.ima20anos. ima.mg.gov.br/intranet/nova/gda/sanidade\%20suidea/29-7Manual\%20 de\%20Padronizacao\%20Criatorios\%20de\%20Suideos\%20versao\%202.pdf

Cademartori BG, Santos LM, Oliveira FC, Quevedo P, Oliveira PA, Ramos TS, et al. Isolation and pathogenicity of Toxoplasma gondii in naturally infected (rustic farm) pigs in southern Brazil. Vet Parasitol 2014; 203(1-2): 207-211. http://dx.doi.org/10.1016/j.vetpar.2014.02.009. PMid:24612744.

Camargo ME. Improved technique of indirect immunofluorescence for serological diagnosis of toxoplasmosis. Rev Inst Med Trop 1964; 6: 117-118. PMid:14177810.

Cavalcante GT, Aguiar DM, Chiebao D, Dubey JP, Ruiz VL, Dias RA, et al. Seroprevalence of Toxoplasma gondii antibodies in cats and pigs from rural western Amazon, Brazil. J Parasitol 2006; 92(4): 863-864. http://dx.doi.org/10.1645/GE-830R.1. PMid:16995406.

Cerqueira-Cézar CK, Calero-Bernal R, Dubey JP, Gennari SM. All about neosporosis in Brazil. Rev Bras Parasitol Vet 2017; 26(3): 253-279. http:// dx.doi.org/10.1590/s1984-29612017045. PMid:28876360.

Dohoo IR, Martin W, Stryhn H. Veterinary epidemiologic research. Charlottetown: AVC Inc.; 2003.

Dubey JP, Gamble HR, Rodrigues AO, Thulliez P. Prevalence of antibodies to Toxoplasma gondii and Trichinella spiralis in 509 pigs from 31 farms in Oahu, Hawaii. Vet Parasitol 1992; 43(1-2): 57-63. http://dx.doi. org/10.1016/0304-4017(92)90048-E. PMid:1496803.

Dubey JP, Hemphill A, Calero-Bernal R, Schares G. Neosporosis in animals. 1st ed. Boca Raton: CRC Press; 2017. http://dx.doi. org/10.1201/9781315152561.

Dubey JP, Lago EG, Gennari SM, Su C, Jones JL. Toxoplasmosis in humans and animals in Brazil: high prevalence, high burden of disease, and epidemiology. Parasitology 2012; 139(11): 1375-1424. http://dx.doi. org/10.1017/S0031182012000765. PMid:22776427.

Dubey JP. Toxoplasmosis in pig - the last 20 years. Vet Parasitol 2009; 164(2-4): 89-103. http://dx.doi.org/10.1016/j.vetpar.2009.05.018. PMid:19559531.

Dubey JP. Toxoplasmosis of animals and humans. 2nd ed. Boca Raton: CRC Press; 2010.

Feitosa TF, Vilela VL, Melo LR, Almeida JL No, Souto DV, Morais DF, et al. Toxoplasma gondii and Neospora caninum in slaughtered pigs from Northeast, Brazil. Vet Parasitol 2014; 202(3-4): 305-309. http:// dx.doi.org/10.1016/j.vetpar.2014.03.015. PMid:24703253.

Garcia JL, Navarro IT, Ogawa L, Oliveira RC. Soroepidemiologia da toxoplasmose em gatos e cáes de propriedades rurais do município de Jaguapitã, estado do Paraná, Brasil. Cienc Rural 1999; 29(1): 99-104. http://dx.doi.org/10.1590/S0103-84781999000100018.

Instituto de Defesa Agropecuária de Mato Grosso - INDEA. Banco de dados do sistema informatizado de animais. Cuiabá: INDEA; 2016.

Jensen L, Jensen TK, Lind P, Henriksen SA, Uggla A, Bille-Hansen V. Experimental porcine neosporosis. APMIS 1998; 106(4): 475-482. http://dx.doi.org/10.1111/j.1699-0463.1998.tb01374.x. PMid:9637270.

Korn EL, Graubard BI. Analysis of health surveys. New York: John Wiley \& Sons; 1999. (Wiley Series in Probability and Statistics). http://dx.doi. org/10.1002/9781118032619

Muraro LS, Caramori JG Jr, Amendoeira MRR, Pereira JA, Oliveira JX Fo, Vicente RT, et al. Seroprevalence of Toxoplasma gondii infection in swine matrices in Nova Mutum and Diamantino, Mato Grosso, Brazil. Rev Bras Parasitol Vet 2010; 19(4): 254-255. http://dx.doi.org/10.1590/ S1984-29612010000400012. PMid:21184704.

R Development Core Team. $R$ : a language and environment for statistical computing, reference index version 2.14.0 [online]. Vienna: R Foundation for Statistical Computing; 2013 [cited 2017 Dec 11]. Available from: http://www.R-project.org

Samico-Fernandes EFT, Samico-Fernandes MFT, Albuquerque PPF, Almeida JC, Santos AS, Mota AR, et al. Toxoplasma gondii in backyard pigs: seroepidemiology and mouse bioassay. Acta Parasitol 2017; 62(2): 466-470. http://dx.doi.org/10.1515/ap-2017-0054. PMid:28426411.

Scheaffer RL, Mendenhall W 3rd, Ott RL, Gerow KG. Elementary survey sampling. 7th ed. Boston: PWS-Kent; 2011.

Tenter A. Toxoplasma gondii in animals used for human consumption. Mem Inst Oswaldo Cruz 2009; 104(2): 364-369. http://dx.doi.org/10.1590/ S0074-02762009000200033. PMid:19430665.

Thrusfield M. Veterinary epidemiology. 3rd ed. Oxford: Blackwell Science; 2007.

Van der Giessen J, Fonville M, Bouwknegt M, Langelaar M, Vollema A. Seroprevalence of Trichinella spiralis and Toxoplasma gondii in pigs from different housing systems in The Netherlands. Vet Parasitol 2007; 148(3-4): 371-374. http://dx.doi.org/10.1016/j.vetpar.2007.06.009. PMid: 17646053 .

Vatcheva KP, Lee M, McCormick JB, Rahbar MH. Multicollinearity in regression analyses conducted in epidemiologic studies. Epidemiology 2016; 6(2): 227. http://dx.doi.org/10.4172/2161-1165.1000227. PMid:27274911. 